Sofija GEORGIEVSKA

UDK: 364-783.442:613.2-053.6

Original research article

\title{
SYSTEMATIC FAMILY APPROACH IN WORKING WITH PEOPLE WITH EATING DISORDERS
}

\begin{abstract}
Eating disorders have been known since ancient times, but nowadays they have undergone many changes. The first records of eating disorders have been observed since ancient times, with the Roman emperors, etc. There are written documents on the starvation and end of the menstrual cycle in nuns, since the ninth century. Seneca, for the then lifestyle, said: "People eat to repent and vomit in order to be able to eat again." It essentially represents the difference in the way and style of life and today's diet, where the main goal is to reduce of body weight.

Eating disorders indicate unhealthy eating habits, the attitude to food, and the maintenance of body weight, and a common feature of all dietary disorders is the perception of the body's perception. Diseases of eating disorders are a significant psychological, sociological and general health problem. The latest world research and their results show that it is necessary to invest on the prevention of these diseases, on the adequate training and education of parents in the formation of healthy eating habits among children, education of the medical personnel in early recognition and risk detection, and later and diseases of eating disorders, education by schools and other professionals who have contact with the population at risk of developing a disorder in the diet. Adolescents represent the most at risk of developing a dietary disorder of any kind, as confirmed in the research. The influence of the modern way of life, the influence of the media, peers, and the whole socio-cultural pressure on the person, and many other external factors, encourage and increase the number of people with eating disorders.
\end{abstract}

Keywords: EATING DISORDERS, ADOLESCENTS, PSYCHOTHERAPY

\section{Introduction}

Dietary behaviour disorder means unhealthy eating habits or eating behaviour and weight maintenance. A common feature of all dietary disorders is the perception of the shape of one's own body (Чадловски, 2004). The exact limit between normal nutrition and eating disorders is not easy to determine. Therefore, many people do not recognize that their attitude to diet is inadequate. Bad habits or unhealthy diets lead to or already represent 
the disease. In people with eating disorders, food is thought to be misused in a subconscious way to help with emotional and other problems.

The classification of eating disorders is based on the visible consequences, such as extreme weakening or obesity, or based on altered patterns of dietary behaviour, such as starvation, eating restriction or overeating. Eating disorders include diarrhoea disorders. According to V. Vuic (Чадловски, Филиповска, Белевска, 2004), instincts would be the mechanisms that a man moves for different activities. The drive for nutrition and the drive for living are driven by self-preservation and fall into the basic, vital and primitive urges. Eating disorders can be quantitative and qualitative (Чадловски, Филиповска, Белевска, 2004).

\section{Quantitative disorders in eating}

Decreased or lost feeling of hunger (oligophage or anorexia) is encountered in certain mental disorders, especially in mental anorexia, depression, schizophrenia, and in the organic psycho syndrome. Anorexia neurosis is characterized by complete ejection of the diet, which reduces anxiety due to disorder of the I - concept. This is usually done by not taking food or plentiful food, followed by vomiting. Most often, it starts with diets for young people, and this is because of the feeling of shame from its appearance, because of a violation of the mental pattern of the body, as a way of punishing or as a result of a discrepancy between the sexual needs of the person and the religious norms.

Increased hunger (polophage or painful insensitivity) may become pathological insufficiency, bulimia. In this case, a large amount of food is consumed, without order and in a short period of time. It occurs in mentally retarded people, in brain tumours, dementia, progressive paralysis, as an epileptic aura followed by intense hunger.

\section{Qualitative disorders in eating}

- Pique is an unusual need for certain food products (sour, sweet) and is most commonly found in pregnant women.

- Copropagia is eating of your own or someone else's excrement.

- Anthrophagia or cannibalism is eating human flesh. It still exists in some wild tribes in Africa or South America. It can also be practiced in cases of natural disasters, as a last resort for survival.

- Anecrophia is eating meat from dead people.

Coprophia, anthropophagia, and necrophagia are very difficult psychopathological disorders that are found in advanced schizophrenic process- 
ses and in severe intellectual retardation. In any case, necrophagia may be transient.

Dietary disorders according to ICD-10 are "behavioural syndromes with physiological disorders and physical factors" (Чадловски, 2004)

\section{Nutrition disorders:}

- Anorexia nervosa;

- Atypical anorexia nervosa;

- Bulimia nervosa;

- Atypical bulimia nervosa;

- Excessive food intake combined with other psychological disorders;

- Vomiting associated with other psychological disorders;

- Other eating disorders;

- Nonspecific eating disorders.

The broadest and most commonly used classification of nutritional disorders includes the following forms (Kontic, 2008):

- Anorexia nervosa AN, restrictive and purgative type;

- Bulimia nervosa BN, purgative and non-purgative type;

- Non-specific nutritional disorders (ED-NOS);

- Eating disorders in childhood.

According to ICD-10 (Чадловски, 2004), anorexia is a disorder characterized by deliberate weight loss, which the patient maintains for a long time and causes it with persistent hunger, severe physical exercise, or by deliberately causing vomiting or frequent stools (with regular or overtime laxatives).

According to DSM-4 (Чадловски, 2004), it is a disorder characterized by the refusal of the subject to maintain normal body weight, the concern not to become overweight, and the disorder of the perceptions of the shape and size of one's own body.

Diagnostic criteria for diagnosing anorexia nervosa are (Kontic, 2008):

- Reduction of food intake and maintenance of minimum body weight or deliberate loss of $1 / 4$ of the initial body weight in adults or an impossible achievement of body weight for age and height in children, resulting in a body weight of at least $15 \%$ below the expected weight for the age and height;

- The emergence of intense fear of eventual weight gain, even when it is far below expected;

- Disturbance of the perception of body image, i.e. uncritical assessment of body image and body weight; 
- Amenorrhoea in postmenarchal women (loss of menstruation in the last three months). Amenorrhea is also considered in cases where a regulated menstrual cycle is maintained only by hormonal therapy.

Bulimia nervosa is a disorder characterized by subsequent excessive foods (overeating) and inadequate compensatory methods to prevent weight gain by which the subject is overly preoccupied. To set the diagnosis (according to the DSM-4 diagnostic criterion), overeating and inadequate compensatory behaviour must be present at an average of at least twice a week for a period of three months. Basic characteristics of BN are:

- Intermittent and seemingly uncontrolled episodes of rapid intake of large amounts of food in a short period of time;

- The most commonly used food is high calorie, easily available and pre-cooked;

- Input of calories above 5000 and 20000 during one episode;

- Eating disorders of eating are especially manifest in the evening;

- Most patients, each food intake end up with induced vomiting, which over time becomes reflex;

- Emotional difficulties such as depression, impulsivity, anxiety and social retreat, where self-assessment, self-esteem and self-esteem are exclusively dependent on the outer appearance and body dimensions.

Non-specific nutritional disorders (ED-NOS) cover a wide range of symptoms and signs, which often intertwine with each other. In 1980, a new diagnosis was called - nonspecific eating disorders. It is defined as a specific and atypical form of an eating disorder, and in clinical practice it is accepted as a separate category. Statistics show that this disease is the most common form of eating disorder from all disorders, and most commonly occurs in obese and nourished persons. This diagnosis is made in the following cases:

- in post menarche women who have a regular menstrual cycle;

- In cases when all the criteria for AN are met, except significant weight loss that is bordering on the normal. This type is found in people who were obese, but with restrictive and strict diets, over time, they weakened and became preoccupied with their weight and appearance;

- Repeated chewing of large amounts of food, but without swallowing, but by spitting food;

- Night overeating syndrome appears as one of the possible responses to the stress organism, after proven disorders in the hypothalamic - adrenal axis, and not as a response to hunger or emotional factors.

Eating disorders in childhood (Tadic, 1992) are most often manifested by food refusals (anorexia), excessive eating (bulimia), slow eating and peak, and less frequent are splanchas and copropathies. 


\section{Treatment of eating disorders}

Adolescence is a period in which the person grows and ripens. The name derives from the Latin word adolescere, meaning growing, matures. Adolescence is most easily determined as a period of tumultuous changes, a period of transition from childhood to adulthood. There are physical, psychological and social changes in it (Мурџева-Шкариќ, 2004).

The onset of adolescence is considered puberty with all the physical and physiological changes that make puberty. Adolescence ends in early adulthood. The criteria for ending adolescence are very different. They are closely related to the developmental stages of adolescence.

In systematic family theory and psychotherapy, a person is seen as part of the family system, with all interactions in the system, including external factors affecting the system.

Salvador Minucin and his colleagues point to the theory of systems that is relevant and appropriate in cases of diarrhoea, especially in anorexia and bulimia (Milojkovic, Srna, Mitchovic, 1997).

From this position, it is said that the symptoms of eating disorders are best understood when considering both the patient and the family, and the symptoms are strengthened in a dysfunctional family structure. In this perception, the child is seen as psychologically vulnerable. This family has several features that help the development of eating disorders.

Childhood eating disorders play an important role in helping the family avoid or conceal other conflicts and problems within the family system.

Much of the important features of Munuchin are for families with children with eating disorders (Minuchin, Fishman, 1981):

1) Networking. Families have an extreme form of exaggerated involvement, involvement and intimacy. Here parents speak about their children because they believe that they know exactly how their children feel.

2) Too much protection. Family members have an extremely high level of caring for one another (troubles for problems).

3) Rigidity. The family tends to support status quo and avoid effective relationships with events that require change (for example: the need of adolescents to do and seek some things in their lives, growing autonomy, etc.).

4) Lack of conflicting solutions. These families avoid conflict or are in a state of permanent chronic conflict.

Systematic family approach - there are two sources for their belief:

1) Personal characteristics of patients with eating disorders. These people are preoccupied with food, they get tired quickly, have a weak concentration, lack of sexual interest, insomnia, irritability, depression, etc. Food 
restriction has powerful effects on personal characteristics and behaviour, so it must be taken into account when evaluating people with an eating disorder. Some studies have a retrospective look at people with an eating disorder.

2) Characteristics of families of patients with eating disorders. In those families there is a high level of conflict, and the statements of parents do not always show a high level of problems, high level of isolation and low level of involvement and support, disturbing family relations, etc. According to Minuchin, they are rigid, emotionally closed, too involved with critical comments and hostility. It also includes abused children (sexual, physical and psychological violence).

According to numerous studies, families with an eating disorder are often too protective, rigid in behaviour, successful, and so on, and the patients feel re-protected or rejected, misunderstood, undefined and lonely. In these situations, mothers are often superior and emotionally cold-blooded, and fathers emotionally or physically absent. Different forms of eating disorders arise as a protection against excessive ideals posed by ambitious parents.

Most often, exposure to stress in childhood, of any kind, maltreatment, neglect, loss of one's parents, etc., increase the risk of emotional problems and behavioural disorders (anxiety, depression, suicide, drug abuse, alcohol and other substances), and is most often accompanied by an eating disorder.

Girls whose mothers have a history of eating disorders are at greater risk of getting an eating disorder, not only because of genetic factors, but also due to poor mothers' influence on children in terms of adopting poor eating habits, weight gain, body appearance, and so on.

There is no template, nor a type of family whose children over the course of their life will have an illness of eating disorders, but most are noticed the following (Kontic, 2008):

- Presence of parental preoccupation with healthy foods, diets, fear of obesity; the child grows and thus identifies. In some cases it is the presence of psychosomatic diseases such as: asthma, migraine, headache, etc.;

- Most of the families showed signs of perfectionism; the child most often grows in a rigid, patriarchal family, and from a minor he is well acquainted with his obligations and rules that he must respect;

- Restraint and failure to express pleasant emotions; everything has to have its own reason, and the only domestic activity in which parents take part are intellectual discussions or reading school books and homework;

- The mother has a superior role, and the father is mostly absent and spent a little time in the home and has no close relationship with the children; 
- In situations where parents have a different attitude towards children; one child is less loved, the other more. In such situations as if the child had been previously selected;

- Poor communication in the family system and visible tension between spouses;

- Neurotic, anorexic, depressed mothers, drug abuse, alcoholism, as well as numerous other psychological disorders are listed in the family history;

- In a conversation with the doctor who called them for involvement in the treatment of their child, they act surprised, not accepting that they are a disease, they are looking for a culprit and so on. The mother is actively involved in the treatment, but often with a self-centred examination of herself, and the father comes rarely.

The last decade has increased the number of studies related to these diseases, as well as attempts to introduce various preventive measures in order to reduce the rate of the disease.

Because of the complex multifactor nature, comprehensive studies are needed to clarify the individual risk factors that independently or jointly contribute to the development of this disease. I think that the need for such research and education is very great. It is needed for professional staff, but also for the wider population.

Diseases of eating disorders is a significant socio-medical, psychological and general health problem of modern civilization.

In order to better understand the risk factors and the symptoms of people at risk, it is necessary to research the general population, which would clarify the influence of those factors and symptoms.

The application of the results of such research should find its place in the integral prevention programs, in everyday practice in primary health care, in food counselling, in specialized departments for treating diseases of eating disorders.

In the world today, there are numerous preventive programs, but not a single strategy. Prevention refers to the elimination of factors that are considered to be triggers (primary prevention) or early detection and treatment of these diseases (secondary prevention).

The primary goal of primary prevention is to reduce the frequency of the onset of the disease and to reduce the frequency of risk factors: social, family and individual, idealizing attenuation, communication problems within the family and dysfunctional elements in families, raising self-esteem and self-esteem and the like. 


\section{Conclusion}

In the choice of the topic, I kept on the psychological indicators of the occurrence of an eating disorder in adolescents. Adolescents are selected as a risky and vulnerable group because the very period of adolescence is rugged and full of change. Preventive programs should start in primary and secondary schools. This means that parents, teachers, teachers, educators, social workers, psychologists, pedagogues, defectologists, gynaecologists, dentists, monoclinologists, coaches and all those who are in contact with these vulnerable groups of adolescents should acquire certain knowledge about diet and for these diseases, risk factors and risk factors.

The latest world data point out that it is necessary to insist on adequate training of parents in the formation of proper dietary habits for their children, from the very first day of life.

As there is an integrative prevention of a variety of diseases, there should also be a prevention of diarrheal diseases, which would include training and education for proper nutrition and feeding habits, prevention of laxatives, diuretics and weight loss products, which would represent protection against obesity and obesity (Kontic, 2008).

Prevention would be integral, multidisciplinary and planned, meaning that on the one hand, the level of awareness about the proper nutrition and diet in the general population will increase, and on the other hand the level of professional staff in the early recognition of this disease. 


\section{References}

Kontic, O. (2008). Anoreksija i bulimija. Beograd. Zadužbina Andrejević

Milojkovic, M., Srna, J., Micovic, R. (1997). Porodicna terapija. Beograd: Centar za brak i porodicu.

Minuchin, S. \& Fishman, H. C. (1981). Family Therapy Techniqes. Cambridge, Massachusetts: Harvard University Press.

Мурџева-Шкариќ, О. (2004). Развојна психологија. Скопје: Филозофски факултет.

Tadic, N. (1992). Psihijatrija djetinstva I mladosti. Beograd: Naucna kniga.

Чадловски, Г. (2004). Психијатрија, Том 1. Скопје: Просветно дело.

Чадловски, Г. (2004). Психијатрија, Том 2. Скопје: Просветно дело.

Чадловски, Г., Белевска, Д., Филиповска, А. (2004). Медицинска психологија. Скопје: Просветно дело. 